\title{
Anatomia de Lorostemon coelhoi Paula, Caraipa valioi Paula e Clusia aff. macropoda Klotzsch (Guttiferae da Amazônia)
}

\author{
José Elias de Paula ( $\left.{ }^{*}\right]$
}

\begin{abstract}
Resumo
Três espécies de Guttiferae foram analisadas anatomicamente, como subsídio taxonômico e ecológico dessa família. As espécies estudadas apresentam estrutura anatômica heterogênea que possibilita a diferenciaçāo dos gêneros.
\end{abstract}

\section{INTRODUÇÃ̃O}

Continuamos, neste trabalho, os estudos sobre Guttiferae que já foram objeto de quatro comunicações (Paula 1966, 1969, 1970a e 1970b). Como estamos organizando uma "chave" para identificação dos gêneros de Guttiferae que ocorrem no Brasil com base, exclusi. vamente, na anatomia de suas madeiras, acreditamos que o estudo anatômico, especialmente do caule, do pecíolo e da lâmina foliar de espécimes dessa família de plantas, poderá auxiliar-nos na elaboração da referida "chave", dando-nos maior segurança quanto aos conceitos genéricos e caracteres afins. Quanto ao gênero Lorostemon, descrito por Ducke (1935). não consta da literatura consultada nenhuma informação sobre a anatomia desse gênero. Por outro lado, tendo side Lorostemon coelhoi descrita há pouco tempo (Paula, 1970b), parece-nos oportuno indicar melhores detalhes do seu aparelho floral, através de desenhos que ajudarăo separá-la das outras três espécies desse gênero: Lorostemon bombaciflorum Ducke, 1935, L. negrense Fróes, 1959 e L. colombianum Maguire, 1958.

\section{MATERIAL}

Utilizamos material fresco e fixado em FAA e FPA de individuos arbóreos. Os espécimes que serviram para confirmar a identificaçâo das espécies encontram-se registrados nos herbários da Universidade de Brasilia (UB) e Instituto Nacional de Pesquisas da Amazônia (INPA), com as informações seguintes:

\section{Lorostemon coelhoi}

a) coletor: J. Elias de Paula 498 (UB); procedência: Amazonas, Manaus, Reserva Florestal Ducke, mata da terra firme, em 18-3-1969.

b) coletor: Luiz Coêlho et Elias 420 (Holotypus INPA); procedência: Amazonas, Manaus, Reser va Florestal Ducke, mata da terra firme, picada 2 , loteamento de base, em 30-6-1967.

\section{Caraipa valioi}

a) coletor: Luiz Coêlho et Elias 419 (Holotypus INPA); procedência: Amazonas, Manaus, Reserva Florestal Ducke, mata da terra firme, picadr 2, loteamento de base, em 30-6-1967.

b) coletor: J. Elias de Paula 475 (UB), material di árvore típica, em 17-3-1968.

Clusia aff. macropoda

a) coletor: J. Elias de Paula, Byron 492 (INPA) et Prance 10455 (NY); procedência: Amazonas, rio Negro, acima da baía Buiuçu, margem do rio, sobre "laterita", em 13-3-1969; determinador, G. Mariz, 1970.

\section{MÉTodo}

Os cortes histológicos foram executados à mão livre, com gilete e com micrótomo rotativo de "Spencer", segundo a técnica da inclusão de material em parafina. Quanto às madeiras, os cortes foram realizados com micrótome Jung para madeira.

Para o estudo do rastro foliar, os cortes histológicos foram realizados em série, no caule, do ápice para a base do nó foliar. Para o esclarecimento da origem dos canais secretores, efetuamos investigações a partir da estrutura primária indiferenciada (meristema primário) de brotos apicais, até a estrutura secundária.

(*) - Universidade de Brasilia, D.F. 
Os compostos fenólicos, goma-resina, lignina e celulose foram identificados por meio do teste metacromático (O'Brien et al. 1964). Quanto à lignina, realizamos, também, o teste com Floroglucina.

Os grãos de amilo foram identificados por apresentarem coloração roxo-azulado em reação com Lugol e, também, sob luz polarizada, de cujo efeito resulta uma zona escura denominada "Cruz de Malta".

As fotomicrografias foram obtidas através do Fotomicroscópio Wild. Adotamos a terminologia de Milanez \& Miranda Bastos (1960), Kribs (1935), Esau (1959), Metcalfe \& Chalk (1957), e a recomendada pela Primeira Reunião de Anatomistas de Madeiras, 1936 (Rodriguésia, 1937).

\section{RESUltados}

\section{Lorostemon coelhoi Paula \\ (fig. 1 a 3 e fotos 1 a 8 )}

\section{CAULE}

Estrutura primária diferenciada (fig. 1-b) - Epiderme glabra; as células epidérmicas, vistas em secção transversal são bastante altas, com base ampla, deltóides ou retangulares, com paredes periclinais externas com cerca de $18 \mu \mathrm{m}$ de espessura, cutinizadas. A cutícula é fina, muito sinuosa.

Colênquima - Examinando cortes de material fresco, em meio aquoso, observamos que - colênquima é pouco característico, pois, consta de 3 a 7 camadas de células de paredes moderadamente espessas, pectocelulósicas, deixando entre si pequenos meatos; essas células, geralmente são ricas em grãos de amilo, e entre elas ocorrem idioblastos contendo drusas de oxalato de cálcio.

Parênquima cortical - Consta de células de forma e diâmetro muito variados, em geral com tanóides, dotadas de paredes pectocelulósicas; são freqüentes nesse parênquima, lacunas aeriferas, de tamanho variado; os canais secretores são abundantes, ocorrem, desde da porção mais externa, até a mais interna desse parênquima.

Sistema vascular - Os elementos vasculares primários estão reunidos em um cilindro

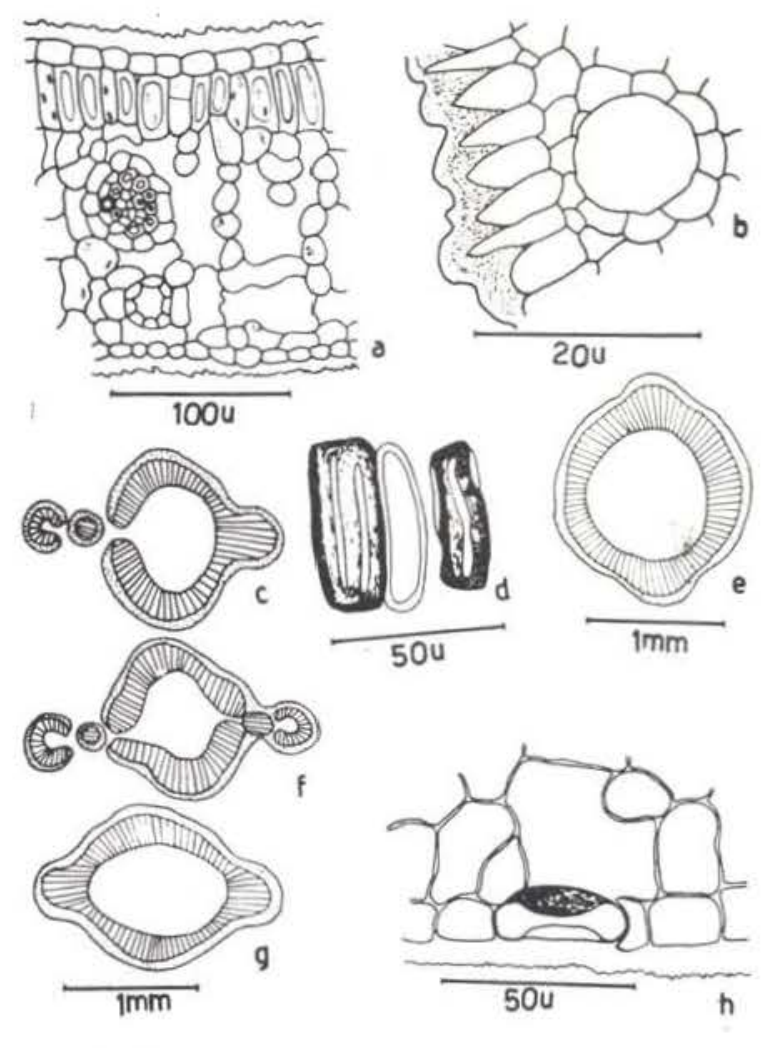

Fig. 1 - Lorostemon coelhoi - a) corte trans versal da lâmina foliar, onde se vêem um feixe vascular envolvido por uma bainha fisiológica, um ca. nal secretor e grandes lacunas; b) caule: estrutura primária mostrando a epiderme e um canal; c) sis. tema vascular do nó foliar na altura da metade de seu comprimento, onde se vêem os cordōes vasculares do rastro foliar; d) células do parênquima paliçádico dissociadas; e-g) sistema vascular da base do nó foliar; f) sistema vascular da porçăo mais alta do nó foliar, mostrando doís cordōes vascula. res do rastro foliar; h) estômatos em secção transversal.

vascular, constituindo, assim, uma estrutura sitonostelo-ectoflóica; os vasos lenhosos aparecem em séries radiais de 2 a 5 elementos. $\mathrm{Na}$ estrutura primária ainda pouco diferenciada já observamos cordōes esparsos de esclerênquima, pela face externa do floema $e$ que au mentam de espessura com a diferenciação plena dessa estrutura. Analisando cortes longitudinais, verificamos que o esclerênquima em apreço é constituído de fibras, na sua maioria. e de esclerócitos.

Parênquima medular - Nessa fase de diferenciação, as células mais ceritrais desse parênquima possuem paredes espessas, lignifi- 

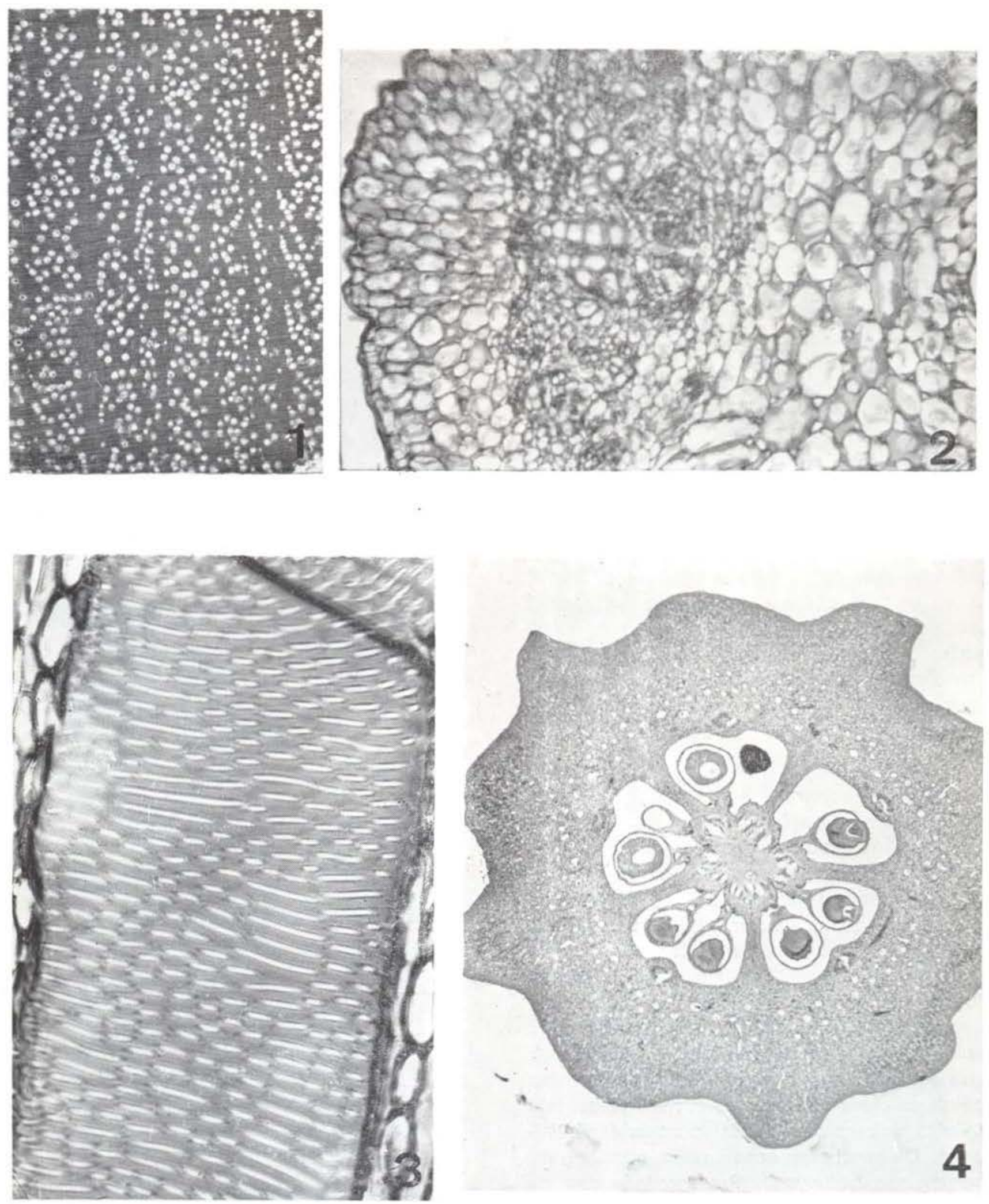

Lorostemon coelhoi: Foto 1 - Aspecto macroscópico da madeira 8x); Foto 2 - Corte transversal de um carpelo mostrando epiderme interna, um feixe vascular (138x); Foto 3 - Pontuações intervasculares (672x' Foto 4 - Ovário em corte transversal (20x) 
cadas: mais tarde, todas as demais células aparecem esclerosadas por espessamento e lignificação de suas paredes. São freqüentes canais secretores situados na parte mais externa da medula.

\section{Estrutura secundária}

Inicialmente, quando já se observam várias camadas de células suberosas, a epiderme ainda permanece íntegra, cujas células são altas e deltóides, com paredes periclinais externas muito espessas. O felogênio, subepidérmico, forma quase que somente súber, que consta somente de um tipo de células: as suberosas típicas. O esclerênquima já forma uma bainha contínua pela face externa do floema secundário. Os raios do floema e do xilema são predominantemente unisseriados, cujas células, em geral, são gomífero-resiniferas; os poros aparecem, nos cortes transversais, em séries radiais de 3 a 8 elementos; as fibras ocorrem mais na parte mais interna do xilema. Com pouca freqüência, ainda se formam canais secretores, na zona cambial, e, também no feloderma. A medula, como já notificamos, aparece totalmente esclerosada; notamos, porém, que as células "epiteliais" dos canais medulares permanecem com paredes finas, pectocelulósicas.

Canais secretores - Analisando cortes transversais e longitudinais de brotos apicais de caule, observamos que, os primeiros indicios de um canal são notados na fase meristemática, quando já são observadas a protoderme, o parênquima fundamental cortical, o procâmbio e o parênquima medular, aliás, esses indícios aparecem primeiro no parênquima fundamental cortical, mais tarde, na medula. Os esboços de canais iniciais são identificados pelo aparecimento de um espaço intercelular que aumenta gradativamente com as divisōes celulares - fase esquizógena e, mais tarde, tais células sofrem lise parcial ou total-fase lisigena. Os canais em questão são, portanto, de origem esquizolisigena. Prosseguindo com as investigaçōes, em fases ulteriores, constatamos que os canais se formam também nas estruturas primária"diferenciada e secundária, pelo mesmo processo. O produto de secreçăo desses canais são tanóides e goma-resina.
Rastro foliar - Na portão inferior do nó foliar, observamos no cilindro central 2 lobos opostos que representam as regiōes donde se deslocam os cordões vasculares do rastro foliar ( fig. 1-g, e ); a partir da metade da altura do nó foliar, 2 cordōes vasculares opostos, um a um se deslocam, em níveis diferentes, do cilindro central e vão se afastando, paulatinamente, até constituir o sistema vascular da ex. tremidade proximal do pecíolo de cada folha oposta. O rastro foliar é, portanto, constituído de un cordão vascular e o nó é bilacunar. No-

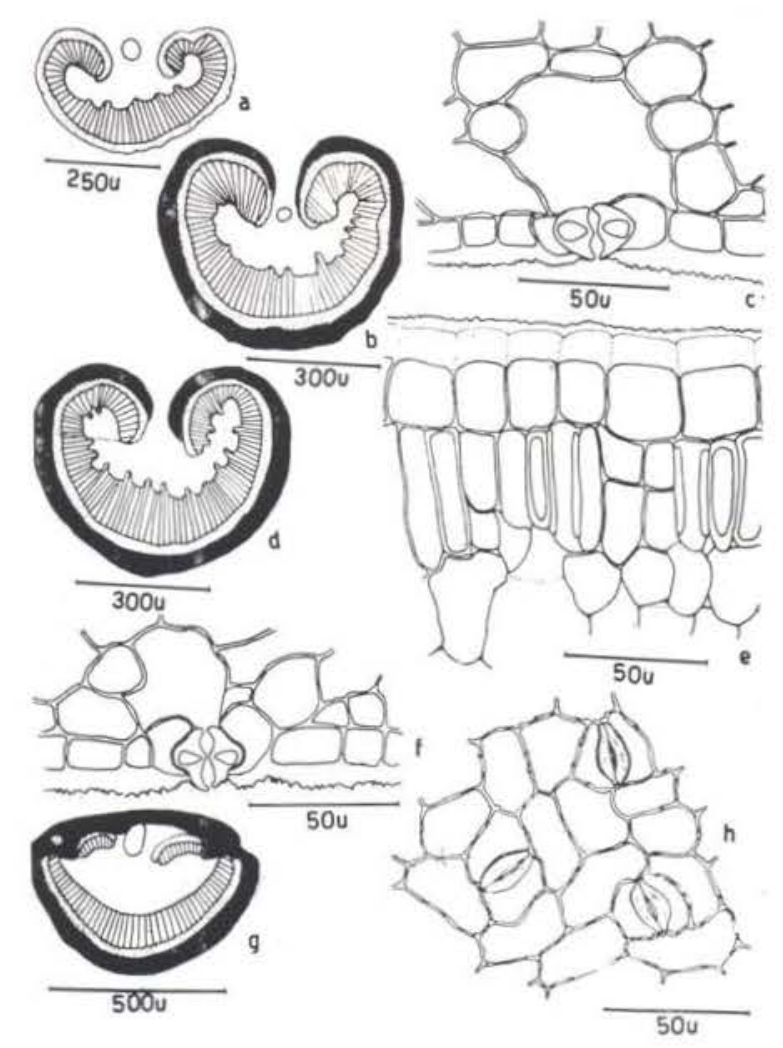

Fig. 2 - Lorostemon coelhoi - a) sisteme vascular da extremidade proximal do peciolo; b) sistema vascular da porção média do pecíolo (o esclerênquima está representado pela parte preta); c) estômato em secção transversal, passando pela região polar; d) sistema vascular da extremidade distal do pecílo (o xilema está representado por traços radiais); e) lâmina foliar em corte transversal, onde se vêem, esquematizados, as paredes periclinais externas das células epidérmicas, parênquima paliçádico e parte do lacunoso; f) estômato em corte transversal passando pela região mediana; g) sistema fibrovascular da nervura central; h) epiderme abaxial em vista frontal. 

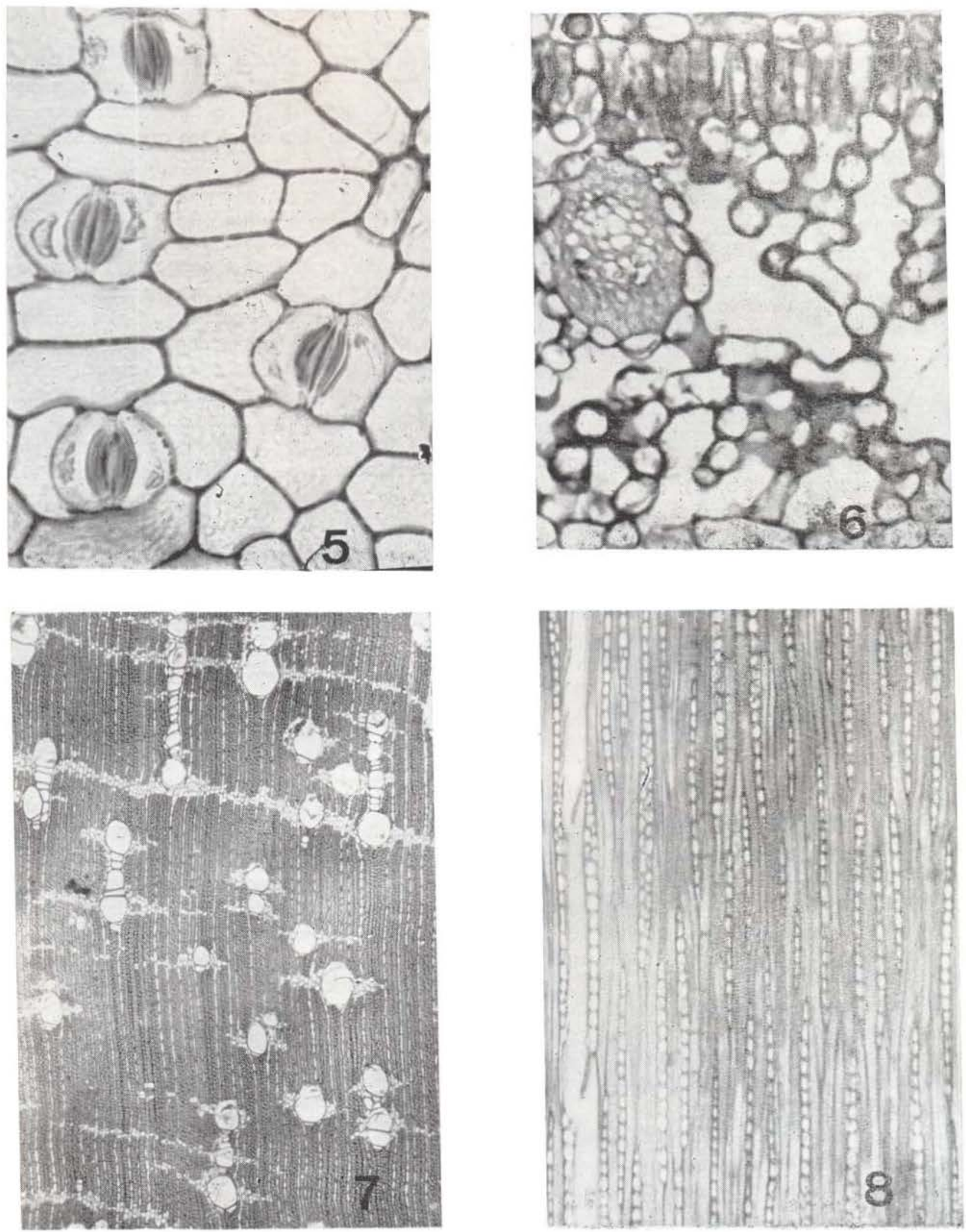

Lorostemon coelhoi: Foto 5 - Epiderme abaxial $(305 \mathrm{x})$; Foto 6 - Corte transversal da lamina foliar $349 \mathrm{x})$; Foto 7 - Corte transversal da madeira (100x); Foto 8 - Corte tangencial da madeira (100x). 
tamos que cada cordão vascular, ao se deslocar do cilindro central, já aparece em forma de um arco (fig. 1-c, f, g).

\section{PECIOLO}

A epiderme é glabra; células epidérmicas. vistas em secção transversal apresentam forma deltóide e possuem paredes periclinais externas bastante espessas, cutinizadas. $\mathrm{O}$ parênquima fundamental é rico em idioblastos contendo drusas de oxalato de cálcio e canais secretores. O sistema vascular, visto em secção transversal, tem forma de um arco contínuo, com as extremidades infletidas, em todo o comprimento do pecíolo ( fig. 2-a, b, c) ; a partir da metade inferior do comprimento do pecíolo, o referido arco vascular é acompanhado, pela face externa do floema, por esclerênquima contínuo ( fig. 2-b, d); em algumas regiões aparece câmbio vascular e a parte externa do xilema é rica em fibras espessas.
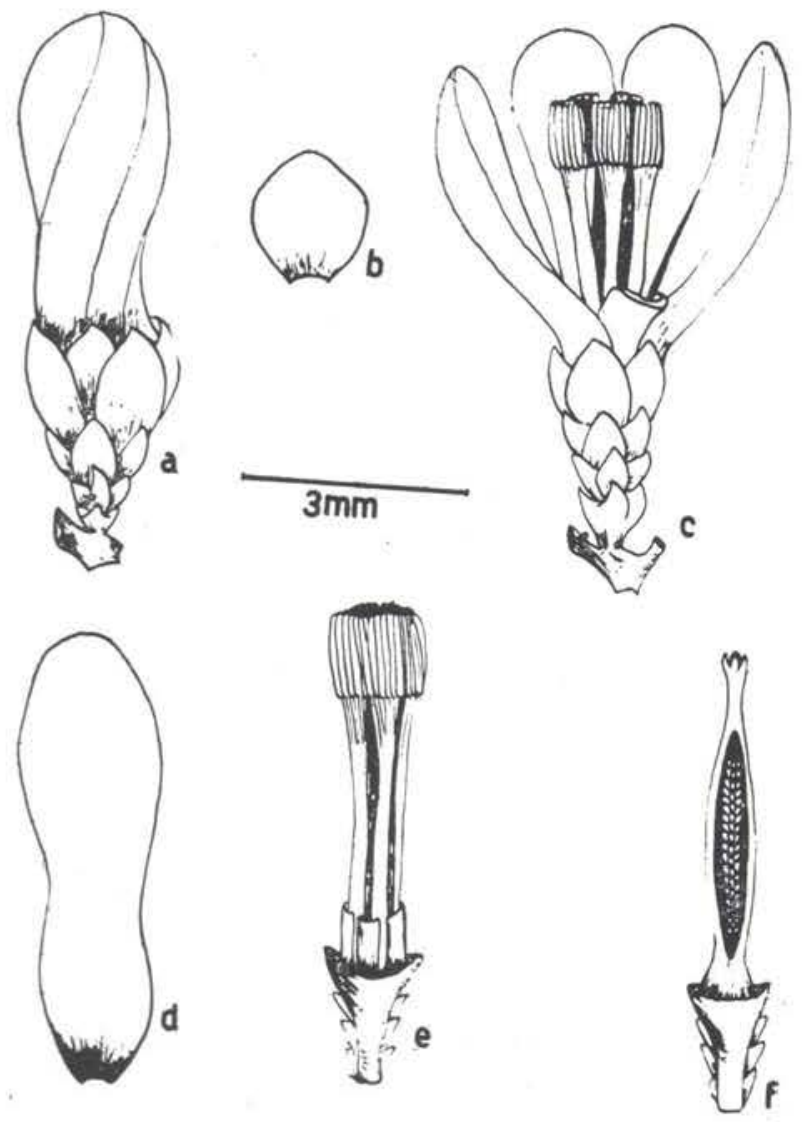

Fig. 3 - Lorostemon coelhoi - a) botão floral; b) sépala; c) flor; d) pétala; e) estames; f) ovário seccionado longitudinalmente.

\section{LAMINA FOLIAR}

Epiderme adaxial glabra; as células epidérmicas, vistas em cortes transversais, apresentam maior diâmetro tangencial; umas são taníferas ao lado de outras que contêm gomaresina; suas paredes periclinais externas são espessas ( fig. 2-e ), pectocelulósicas; cutícula senso lato crenulado, com cerca de 18 a $22 \mu \mathrm{m}$ de espessura; vista de face, as células epidérmicas são tipicamente poligonais, cujas paredes são sempre retas, com pontuações simples. A epiderme abaxial (fig. 2-h) é igualmente glabra; células epidérmicas, vistas em secção transversal apresentam forma retangular, com maior diâmetro tangencial, sāo tão grandes quanto as da epiderme adaxial, com paredes finas, pectocelulósicas; cutícula crenulada, com cerca de $10 \mu \mathrm{m}$ de espessura. Vista de face, as células epidérmicas são de forma e tamanho muito variados, com paredes dotadas de numerosas pontuações simples (foto 5 ). O parênquima paliçádico consta de uma camada de células de paredes, geralmente espessas (fig. 2-e, fig. 1-a, d', foto 6), especialmente nos angulos, parcialmente lignificadas, cujo teor de lignina aumenta na medida que as foIhas envelhecem; são freqüentes células paliçádicas que sofreram mais uma divisão tardia por formação de paredes periclinais. O parênquima lacunoso (fig. 2-c, f, foto 6 ) corresponde a dois terços da espessura total do mesófilo; as lacunas são numerosas e grandes; sâo freqüentes células contendo goma-resina; os feixes fibro-vasculares são envolvidos por uma bainha fisiológica (de Heberlandt), constituída de células amplas de paredes moderadamente espessas, pectocelulósicas; nesse parênquima ocorrem canais secretores.

Nervura central - No parênquima fundamental são freqüentes espaços aeríferos e canais secretores; o sistema fibrovascular, visto em secção transversal tem forma subdeltóide ou subcircular (fig. 2-g), dependendo da região. Na face adaxial da nervura há uma camada de células subepidérmicas, semelhantes às paliçádicas, com paredes moderadamente espessas, pectocelulósicas, às vezes lignificadas.

Estômatos - São tipicamente paracíticos (rubiáceos); ocorrem somente na epiderme 
abaxial (fig. 2-h e foto 5) numa média de 115 estômatos por $\mathrm{mm}^{2}$, variando entre 113 e 118 : nas células guardiãs, vistas de face, observamos grãos de amilo. Em corte transversal verificamos que o aparelho estomático possui uma câmara subestomática bastante ampla (fig. 2-c, f); as paredes das células guardiãs que confinam o ostíolo possuem espessamento cutinizado que forma, nos "bordos". interno e externo, duas "cristas" que limitam um átrio interno e outro externo, respectivamente (fig. 2-c, f); em corte longitudinal, observamos que o lúmem das células guardiãs é um pouco estreito, na porção mediana (fig. 1-h); esse caráter é também notado no corte transversal, ao nivel da região mediana (fig. 2-f). Quanto aos parastomatócitos, registramos a presença de pequenos glóbulos de óleo-resina.

\section{MADEIRA}

A madeira de Lorostemon coelhoi é cura, pesada; casca fina, aspero-rugosa; alburno bege; cerne distinto do alburno, castanho-claro ou amarelado; poros indistintos a olho nu; parênquima axial em faixas estreitas, moderadamente sinuosas; raios muito estreitos, lon* gos; o conjunto de raios lembra verdadeiras estrias, vistos de topo (foto 1).

Descrição microscópica - Poros: distribuição moderadamente regular, de secção circular a ovóide, com maior diâmetro radical; solitários ou múltiplos de 2-3 ou em séries radiais de até 16 elementos (foto 7); os solitários e os múltiplos de 2-3 sāo bem maiores que os múltiplos em séries, cujo diâmetro diminui na medida que aumenta o número de elementos em cada série; os solitários apresentam uma média de $129 \mu \mathrm{m}$ de diâmetro radial (médios). variando entre 64 e 204, sendo $49 \%$ entre 11 e 140; os múltiplos apresentam uma média de $71 \mu \mathrm{m}$ em diâmetro radial (pequenos), variando entre 25 e 179 , sendo $45 \%$ entre 51 e 100 : considerando os múltiplos como unidade, a média é de 7 por $\mathrm{mm}^{2}$ (pouco numerosos), variando entre 5 e 9; por outro lado, considerando cada poro das séries como uma unidade, a média é de 28 por $\mathrm{mm}^{2}$ (muito numerosos), varjando entre 18 e 35 , sendo $53 \%$ entre 24 e 31. Elementos vasculares muito curtos, $0,7 \mathrm{~mm}$ de comprimento, variando entre 0,56 e 1,006, sendo $60 \%$ entre 0.46 e $0,83 \mathrm{~mm}$; pontuações intervasculares (foto 3) alternas ou em grupos. escalariformes, de elípticas a alongadas horizontalmente, especialmente nos traqueóides e nas bases dos elementos dos vasos, numerosas; fendas amplas, alongadas. Parênquima axial moderadamente abundante ou escasso, paratraqueal confluente pouco típico, às vezes brevialiforme, em faixas tangenciais longas ou curtas, em geral estreitas, ou em grupos de 1 a 6 células (foto 7); as faixas de parênquima constam de 1-4 células de largura; muitas dessas células contêm goma-resina. Raios (foto 8) freqüentemente unisseriados, raramente bisseriados, homogêneos, tipo I de Kribs; com 2 a 57 células em altura, raramente 64 , sendo mais freqüentes entre 30 e 43 ; muito numerosos, 16 por $\mathrm{mm}$, em média, variando entre 15 e 20 ; muito baixos, $9,7 \mathrm{~mm}$ de altura, em média, variando entre 0,14 e 1,6 , sendo $40 \%$ entre 0,14 e $0,79,31 \%$ entre 1 e 1,6 e $29 \%$ entre 0,40 e 0,80 ; são freqüentes células radiais contendo goma-resina. Traqueóide vasicêntricos, com pontuações igualmente escalariformes. Fibras abundantes, muito espessas, cujo lúmem corresponde a menos de $1 / 3$ da espessura total da fibra; elementos fibrosos curtos, $1,4 \mathrm{~mm}$ de comprimento em média, variando entre $1 \mathrm{~mm}$ e 1,7 , sendo $50 \%$ entre 1,28 e 1,56; pontuações escassas, muito pequenas.

\section{FLOR (fig. 3)}

Botão floral com pétalas contorcidas, parte mediana deprimida e ápice abaulado (fig. 3-a); com 6 a $8 \mathrm{~cm}$ de comprimento e $2-3 \mathrm{~cm}$ de diâmetro; pétalas (fig. 3-c, d) subcarnosas, com 1,5 a $2,5 \mathrm{~cm}$ de espessura, imbricadas, côncavas, base estreita em relação com o ápice; sépalas suborbiculadas a elipticas (fig. 3-b). Analisando pétalas em secção transversal observamos que elas são formadas apenas de um tipo de tecido: o lacunoso, onde ocorrem canais secretores, cujo comprimento é paralelo à superfície da pétala. Os estames (fig. 3-e) estão reunidos em 5 fascículos, cada fascículo com 13 anteras livres; no botão floral, o conjunto das anteras forma uma peça capitada. O ovário (fig. 3-f, foto 2 e 4 ) é longopedunculado, com $3-5 \mathrm{~cm}$ de comprimento e o pedúnculo com $1,5-2,5 \mathrm{~cm}$ de comprimento; com 5 lóculos, cada lóculo com 34 óvulos reunidos aos pares; ovário sulcado longitudinalmente. 
Examinando cortes transversais do ovário observamos uma epiderme interna e outra externa; as células da epiderme externa são bastante altas, em aigumas regiōes elas tomam forma paliçádica, com núcleo bastante grande, enquanto que as células da epiderme interna são estreitas e alongadas tangencialmente. O parênquima carpelar é rico em canais secretores, células, com tanóides, e "lacunas" resultantes da lise de células, em gerai longas e estreitas. Nas proximidades de cada lóculo ocorre um cordão vascular espesso (foto 2), anfiflóico què corresponde à nervura que separa um sulco de outro. Com o desenvolvimento do ovário transformando-se em fruto, os mencionados sulcos văo se tornando cada vez mais profundo e que, visto em corte transversal, lembram criptas.

\section{Caraipa valioi Paula}

(Fig. 4 e 5 e fotos 9-16)

\section{CAULE}

Estrutura primária - A epiderme é densamente pilosa, cujos pêlos são simples, de uni a pluricelulares, às vezes bifurcados, com paredes celulares moderadamente espessas, parcialmente lignificadas; em geral, esses pêlos são ricos em tanóides. O colênquima, pouco característico, consta de 3-5 camadas de células de paredes pouco espessas, deixando entre si, nos ângulos, espaços intercelulares; essas células são ricas em goma-resina, e entre elas ocorrem idioblastos contendo drusas de oxalato de cálcio. O Parênquima cortical é rico em goma-resina; além dos idioblastos cristaliferos, ocorrem canais secretores esquizolisígenos, cujo processo formador é o mesmo descrito na espécie anterior (foto 9). Quanto ao sistema vascular primário, o caule de Caraipa valioi apresenta estrutura do tipo sifonostelo-ectoflóica. No parênquima medular, também ocorrem drusas de oxalato de cálcio e canais medulares; as cédulas desse parênquima são igualmente ricas em goma-resina.

Estrutura secundária - Num estágio da estrutura secundária, quando o felogênio subepidérmico já está em atividade plena e a medula aparece" quase totalmente esclerosada, por espessamento e lignificaçăo de suas paredes, observamos que o câmbio vascular ain- da năo se diferenciou e o xilema apresenta características tipicamente primárias (foto 13); ressalte-se que, somente mais tarde, em fases ulteriores é que o câmbio começa sua atividade. $\mathrm{O}$ súber consta de dois tipos de células: as suberosas tipicas e os esclerócitos que se apresentam com maior diâmetro tangencial. $\mathrm{Na}$ estrutura secundária, pelo menos, no material examinado não se formam canais secretores. os que observamos são formados na estrutura primária.

Rastro foliar - Conforme ilustram os desenhos $a$ e $b$ da figura 5 , o rastro foliar de Caraipa valioi é constituído de um feixe vascular e o nó foliar é, portanto, unilacunar. Queremos chamar atenção para a presença de uma bainha de esclerênquima ao nivel do nó foliar, na estrutura primária, a qual não ocorre no entre-nó (fig. 4-e).
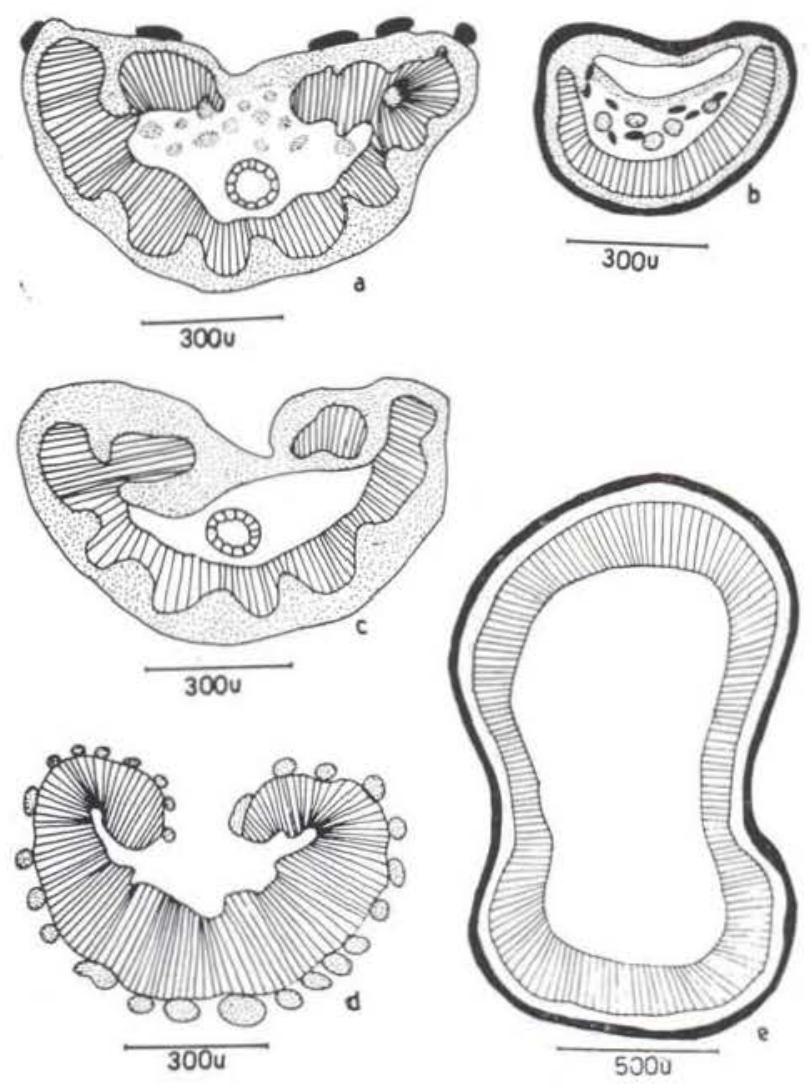

Fig. 4-Caraipa valioi - a) sistema vascular da extremidade distal do pecíolo; b) sistema fibrovas. cular da nervura central (o floema está representado pelas partes pontuadas); c) sistema vascular da porçāo média do pecíolo; d) sistema vascular da ex tremidade proximal do pecíolo; e) sistema fibro vascular da porção inferior do nó foliar. 

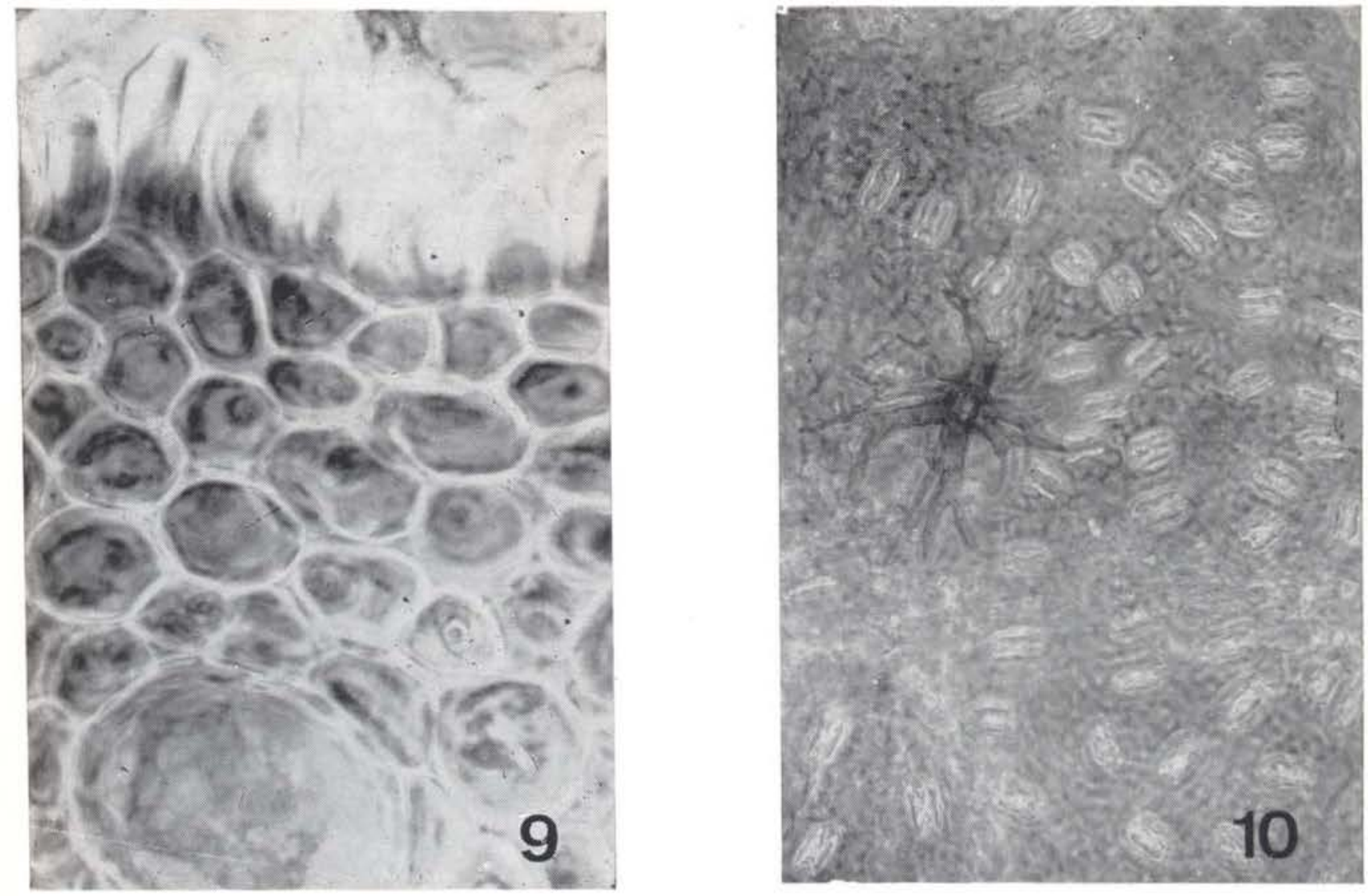

Caraipa valioi: Foto 9 - Estrutura primária do caule mostrando um canal em formação e um canal já formado (305x); Foto 10 - Epiderme abaxial mostrando estômatos e astroesclerócitos (305x).

MADEIRA - dura, pesada; casca fina, dura, lisa; poros visiveis com aumento de $8 x$, abundantes, distribuídos irregularmente; pa. rênquima axial vasicêntrico; raios abundantes. muito estreitos, o conjunto dos raios lembra uma estrutura estriada; textura moderadamen. te grosseira; grã regular; alburno e cerne castanho claros (foto 12).

Descriçâo microscópica - Poros: distribuição moderadamente difusa, geralmente solitários, de secção subcircular ou subovóide, com maior diâmetro radial; pouco numerososs, 9 por $\mathrm{mm}^{2}$ em média, variando entre 6 e 12 , sendo $60 \%$ entre 7 e $8,30 \%$ entre 10 e 12 e. $10 \%$ de 6 ; médios, $152 \mu \mathrm{m}$ de diâmetro em média, variando entre 102 e 192 , sendo $70 \%$ entre 153 e $192,30 \%$ entre 102 e 140 . Elementos vasculares com perfuração simples, parcial ou total, médios, 0,93 $\mathrm{mm}$ de comprimento em média, variando entre 0,7 e 1,17 , raramente
1,7; pontuações intervasculares alternas, ou escalariformes nos traqueóides e nas extremidades dos elementos dos vasos, elipticas, às vezes pouco alongadas, com fenda ampla (fotos 14 e 16). Traqueóides vasicêntricos. Raios unisseriados, homogêneos, tipo I de Kribs, muito numerosos, 13 por $\mathrm{mm}$ em média, variando entre 12 e 16; médios, $0,45 \mathrm{~mm}$ de altura em média, variando entre 0,15 e $0,65 \mathrm{~mm}$, sendo $60 \%$ entre 0,44 e $0,65,40 \%$ entre 0,15 e 0,33 ; com 3 a 20 células em altura, sendo mais freqüentes entre 6 e 11; são freqüentes células radiais contendo goma-rasina. Parênquima axial escasso, paratraqueal vasicêntrico (foto 15). Fibras abundantes, com pontuações areoladas, fendas amplas, fusiformes; elementos fibrosos espessos, cujo lúmem corresponde a cerca de $1 / 3$ do diâmetro total da fibra; médios, $1,5 \mathrm{~mm}$ de comprimento em média, variando entre 1,1 e 1,7 , sendo $80 \%$ entre 1,3 e $1,6 \mathrm{~mm}$. 


\section{PECIOLO}

Epiderme glabra ou pouco pilosa; parênquima fundamental rico em células contendo goma-resina; são freqüentes canais secretores esquizolisigenos nesse parênquima. Os feixes vasculares se dispõem em forma de um arco, vistos em secção transversal (fig. 4-a, c, d), sendo mais típico na extremidade proximal (fig. 4-d), onde o floema aparece em forma ds cordões esparsos.

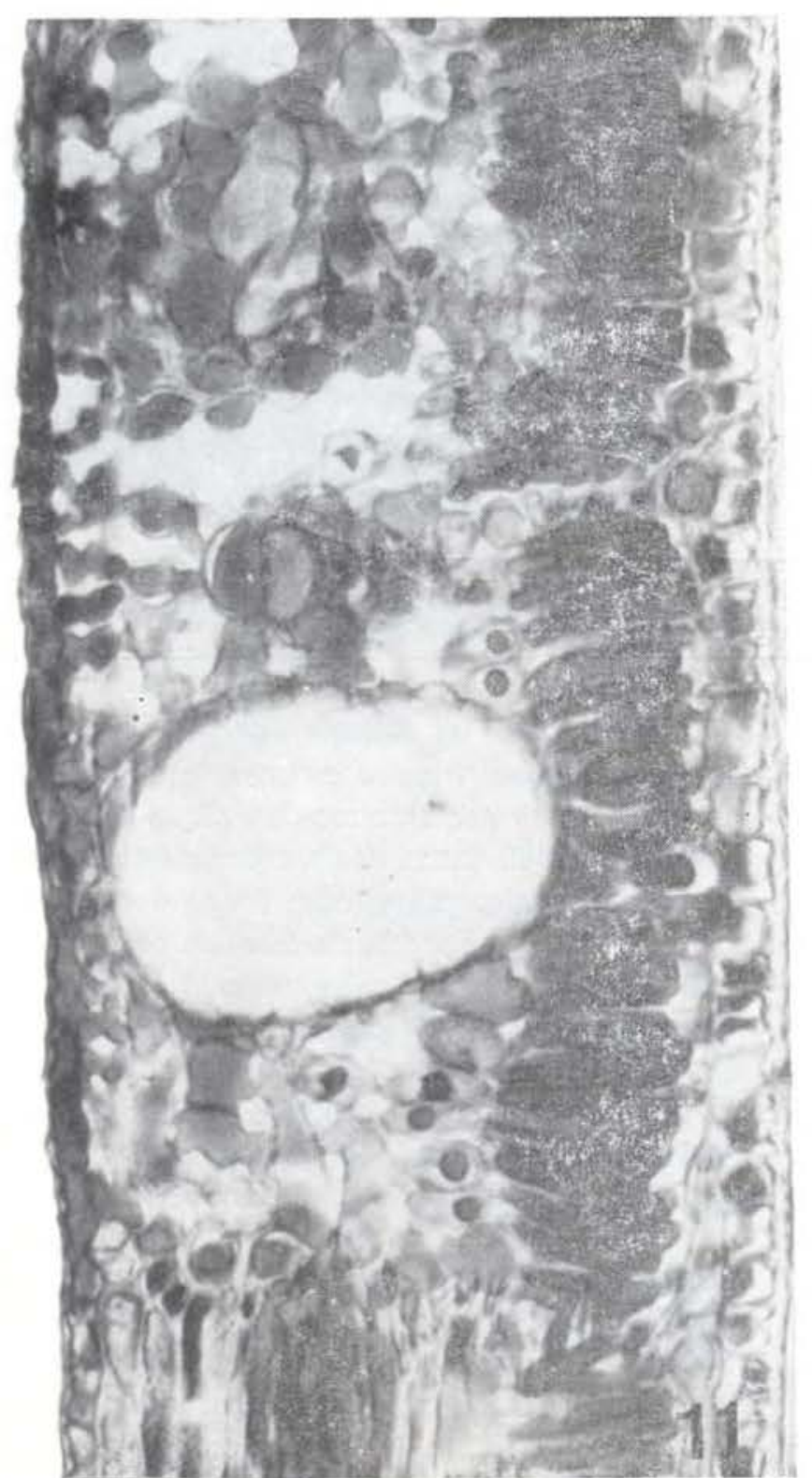

\section{LAMINA FOLIAA}

Epiderme adaxial (fig. 5-e) glabra; as células epidérmicas, vistas em corte transversal apresentam forma e tamanho muito variados. em geral ricas em tanćides; com paredes moderadamente espessas, lignificadas, notadamente as periclinais externas, dotadas de pontuaçōes marginais. Vista de face apresenta células com contorno muito sinuoso (fig. 5-e). Cutícula fina, uniforme. A hipoderme (fig.
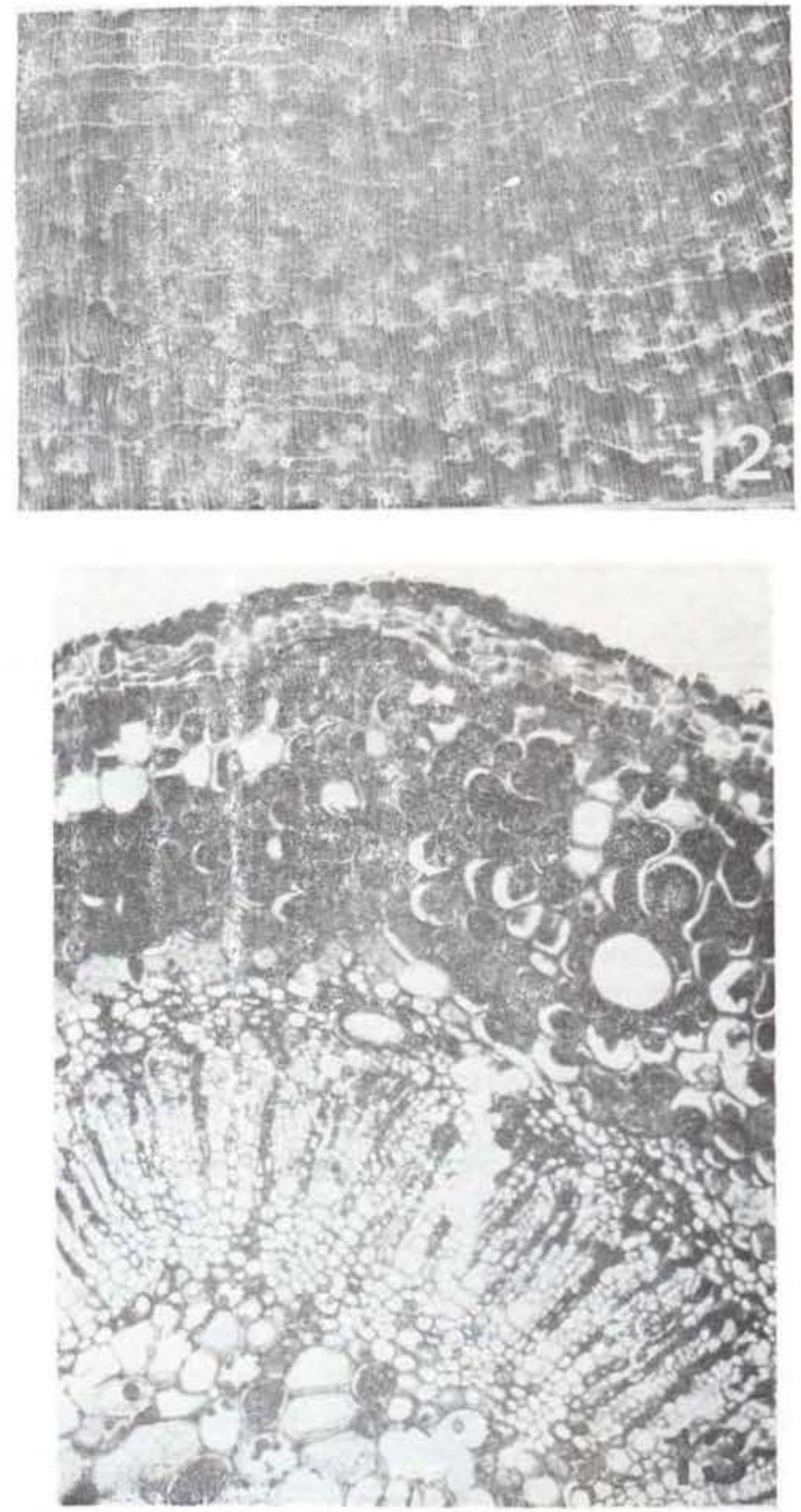

Caraipa valioi $=$ Foto 11 - Corte transversal da lâmina foliar $(349 \mathrm{x})$; Foto 12 - Aspecto macroscópico da madeira $(8 \mathrm{x})$; Foto 13 - Corte transversal do caule mostrando periderme, xilema primário e células polifeniferas $(138 \mathrm{x})$. 

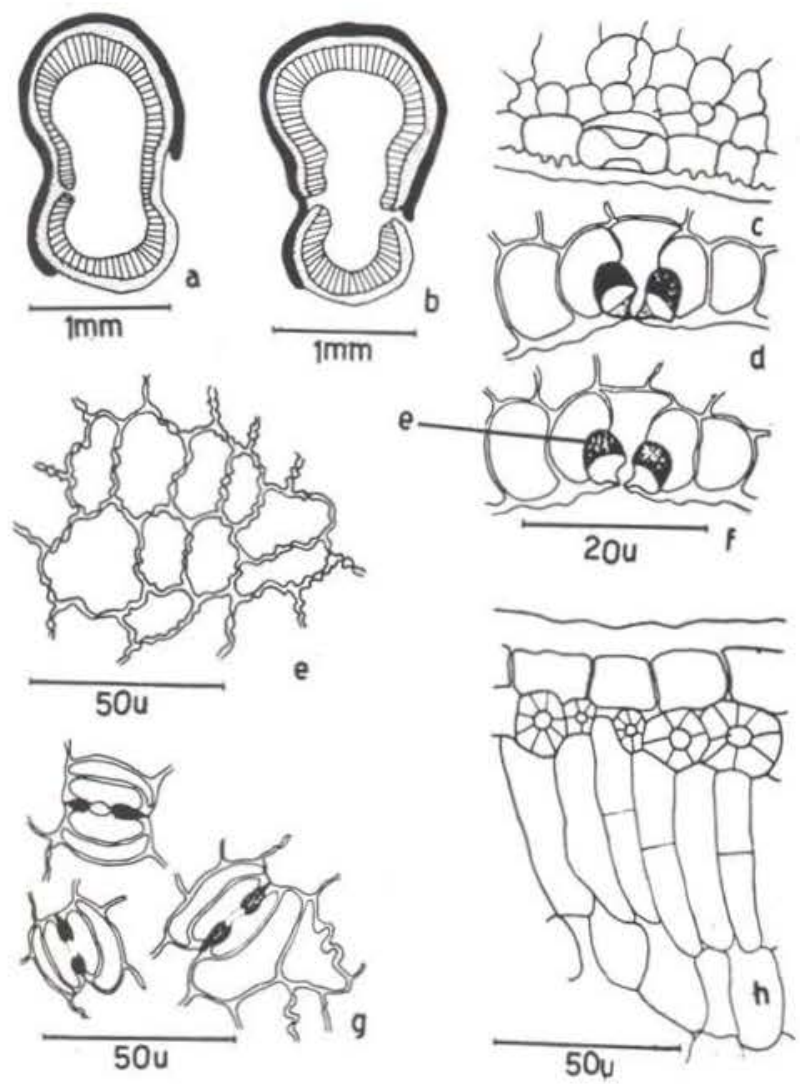

Fig. 5 - Caraipa valioi - a) rastro foliar da porção inferior do nó foliar; b) rastro foliar ao nível da base do pecíolo; c) estômato em corte longitudinal; d) estômato em corte transversal passando pela re. giāo polar; e) epiderme adaxial; f) estômato em corte transversal passando pela região mediana (e, espessamente da célula guardiã); g) estômatos, vista de face; $h$ ) corte transversal da folha mostrando epiderme adaxial, hipoderme esclerosada e células coletoras.

5-h) é constituída de uma camada de esclerócitos, com pontuaçōes simples, às vezes ramificadas. Epiderme abaxial (fig. 5-c, d, e, f, g) glabra; células epidérmicas alongadas tangencialmente, pequenas, em geral com tanóides; paredes finas, pectocelulósicas, raramente lignificadas, com pontuações marginais. Vista de face, as células têm contorno sinuoso, e ocorrem astroesclerócitos (foto 10). O parênquima paliçádico (foto 11) consta de uma camada de células ricas em tanóides. Em geral, essas células sofreram mais uma divisãc tarôla por paredes periclinais (fig. 5-h). 0 parênquima lacunoso (foto 11) é mais espesso do que o paliçádico e consta de células de for- ma e tamanho muito variados, sempre com tanóides; muitas delas possuem paredes lignificadas; as lacunas são amplas e abundantes; nesse parênquima ocorrem canais secretores; os feixes vasculares são envolvidos por esclerênquima que emite projeções, as quais se prolongam até a epiderme abaxial e hipoderme. Nervura central com epiderme pilosa; parênquima fundamental cortical e medular é rico em esclerócitos; a região fibrovascular (fig. 4-b), vista em secção transversal consta de dois arcos assimétricos, sendo um na face abaxial e outro na face adaxial; na parte central da nervura ocorrem cordões de floema medular.

Estômatos (foto 10) - Ocorrem somente na epiderme abaxial, numa média de 717 por $\mathrm{mm}^{2}$, variando entre 713 e 721 ; são pequenos, paracíticos (fig. 5-g); em vista frontal, o aparelho estomático apresenta estrutura muito peculiar: nos "polos", as paredes que delimitam o ostíolc são bastante espessas, cuja cutinização diminui à medida que se aproxima dos polos (foto $5-\mathrm{g}$ ), parecendo que tal espessamento se prolonga até o espaço intercelular; em corte longitudinal (fig. 5-c), observa-se que o lúmem dos estomatócitos é amplo nos polos e estreito na porção mediana; em corte transversal passando pela regiăo polar (fig. 5-d), os estomatócitos apresentam um espessamento externo formando uma "crista" e oultro na face da parede que está para as paredes das parastomatócitos; em outro corte, passando pela região mediana (fig. 5 -f), vê-se que o espessamento externo é reduzido, em comparação com aqueles, e é representado apenas pelo ápice da "crista".

Clusia aff. macropoda Klotzsch (fig. 6 e fotos 17 a 24 )

\section{RAIZ AEREA (fotos 17-18)}

Estrutura primária - A epiderme perece muito cedo, havendo portanto, uma camada de células característicamente exodérmicas, em geral com maior diâmetro anticlinal $\mathrm{O}$ parênquima cortical é amplo, cujas células são habitualmente circulares, vistas em secção transversal, de diâmetro muito variado; nas camadas mais externas do córtex, ocorrem das paredes de células corticais. A endoderme é 


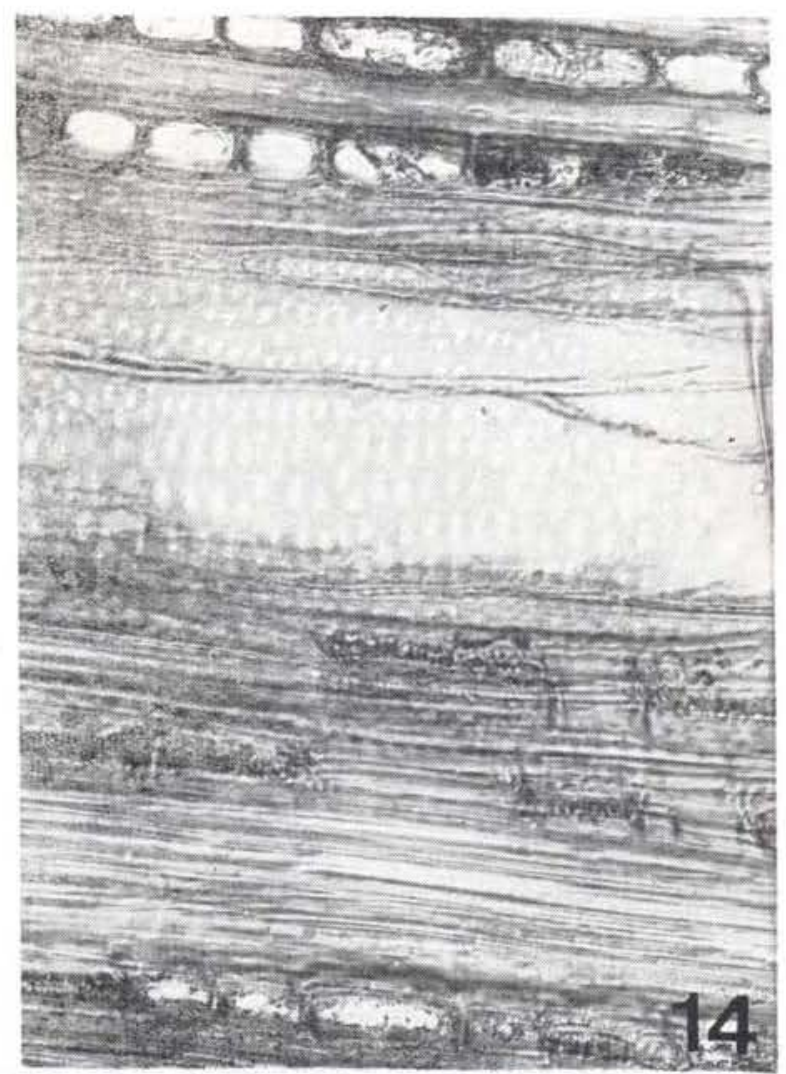

Caraipa valioi - Foto 14 - Pontuaçóes intervasculares (438z); Foto 15 - Corte transversal da madeira $(100 x)$.

bastante característica, suas células, em geral, possuem grãos de amilo. Quanto ao sistema vascular primário, a raíz é poliarca, com 6 a 19 polos de protoxilema e igual número de polos de protofioema (foto 17), dependendo da espessura da raíz. Nas raízes mais espessas há diferenciação de medula, fato que não ocorre nas raizes mais finas. Os canais gomifero-iesiníferos se formam na medula e no parênquima cortical, pelo processo esquizógeno, caracterizado pelo aumento progressivo do espaço intercelular; não observamos, portanto, lise de células, pelo menos nos canais que examinamos em suas fases de formação. $\mathrm{Na}$ região pericíclica há uma bainha amilífera.

Estrutura secundária (foto 18) - Quanto à estrutura secundária, queremos salientar que, o felogênio é subepidérmico, fato que não é comum nas raízes; o felogênio aparece primeiro do que o câmbio vascular; somente mais tarde, quandō̄ já existem 2-3 camadas de células suberosas é que o câmbio entra em atividade plena. Na estrutura secundária não se

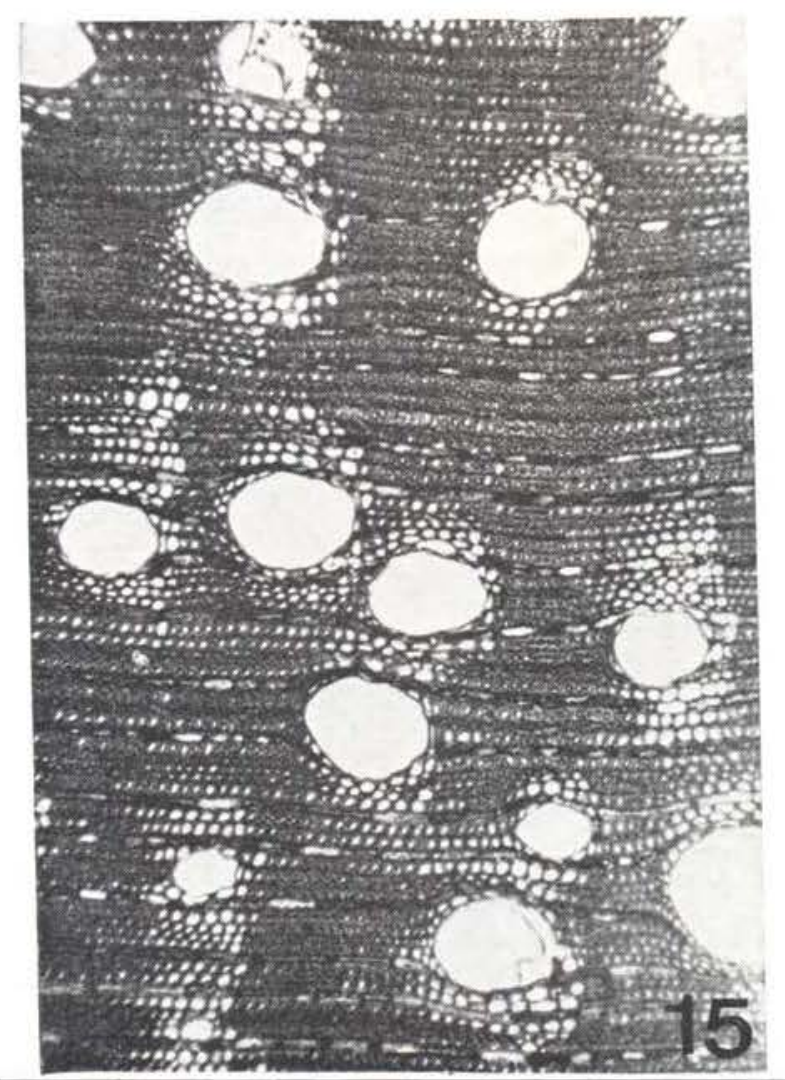

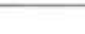

formam canais e os que se observam foram formados na estrutura primária, inativos, isto é, suas células "epiteliais" já morreram.

\section{CAUIE}

Estrutura primária - Epiderme glabra; células epidérmicas, vistas em secção transversal apresentam forma, ora com maior diâmetro anticlinal, ora periclinal, algumas delas săo ricas em tanóides. O colênquima consta de 3-5 camadas de células contendo drusas de oxalato de cálcio, e canais gomífero-resiniferos. No parênquima cortical, os referidos canais são muito abundantes na porção mais externa; esses canais são de origem esquizolisigenos, havendo alguns que são esquizógenos, conforme pudemos observar, analisando sua formação, desde dos primeiros esboços, que começam a partir do meristema primário. Quanto ao sistema vascular primário, o caule apresenta estrutura sifonostelo-ectoflóica; a regiảo vascular, vista em secção transversal, tem forma elíptica; observamos que dois feixes vas- 

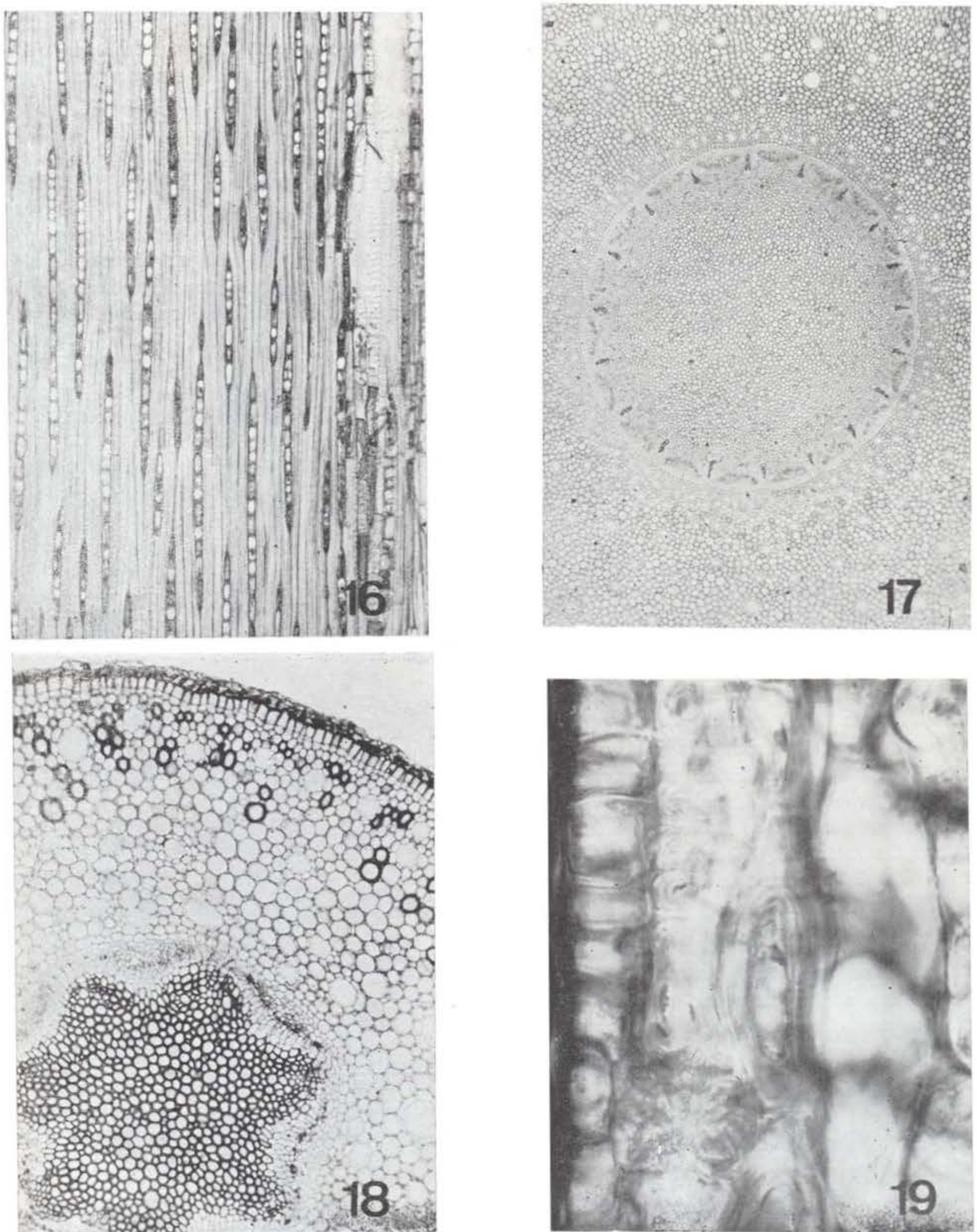

Caraipa valioi - Foto $1 t^{*}$ - Corte tangencial da madeir a $(100 \mathrm{x})$. Clusia aff macropoda - Foto 17 - Corte transwersal da raiz aérea $(60 \mathrm{x})$; Foto 18 - Estrutura secundária da raiz (93x); Foto 19 - Corte transversal da lamina foliar mostrando parte do mesófilo, hipoderme esclerosada e drusas no começo de sua redisso. luçāo (736). 
culares opostos têm forma de arco; mais tarde, nos espaços ocupados apenas por floema é que começam a surgir os vasos lenhosos; por outro lado, a região vascular, ao nivel do nó foliar. vista em secção transversal tem forma circular e a diferenciação dos vasos lenhosos primários se processa por igual em toda a circunferência. $O$ parênquima medular é rico em canais e células contendo tanóides.

Estrutura secundária - $\mathrm{O}$ caule não forma súber, pelo menos no material que examinamos, onde a estrutura secundária apresenta o lenho caracteristicamente secundário, como se vê na foto 23 . A epiderme permanece íntegra, como se suas células dividissem por paredes anticlinais para acompanhar o cresclmento em espessura do cilindro central. As camadas externas do parênquima cortical constam de esclerócitos, ocorrendo entre eles idioblastos cristaliferos. As células parenquimatosas corticais e medulares são ricas em grãos de amilo e dotadas de paredes finas, pectocelulósicas, entre elas, são freqüentes idioblastos cristalíferos. Não observamos canais em formação. Ao contrário das duas espécies anteriores, na região perivascular nâo se diferenciam fibras. No floema săo freqüentes idioblastos contendo drusas de oxalato de cálcio. No lenho secundário, ocorrem poros cheios de goma-resina. Os elementos vasculares possuem pontuações tipicamente escalariformes. Os raios são 2-3 seriados. O parên. quima axial é paratraqueal, escasso. As fibras são espessas, abundantes.

Rastro foliar - O nó foliar é bilacunar e o rastro foliar de cada folha oposta é constituido de um cordão vascular, como se pode observar nos desenhos b, c, da figura 6 e foto 22 .

\section{PECIOLO}

Epiderme glabra; cuticula senso lato ondulada, com espessura entre 16 e $20 \mu \mathrm{m}$; sob as células epidérmicas ocorrem esclerócitos contendo fragmentos de cristais de oxalato de cálcio, ao lado de outros em fase de esclerotização com cristais em redissolução; no parênquima funđamental, ocorrem canais e dru. sas de oxalato de cálcio. Na face adaxial da extremidade proximal do pecíolo săo freqüen- tes espaços aeríferos. no parênquima fundamental. O sistema vascular, em todo o comprimento do peciolo, visto em corte transversal tem forma de um arco, com as extremidades infletidas (foto 21).

\section{LÂMINA FOLIAR}

Epiderme adaxial glabra; as células epidérmicas, vistas em secção transversal, têm forma sub-retangular a retangular, com maior diâmetro anticlinal, em geral com núcleo grande.
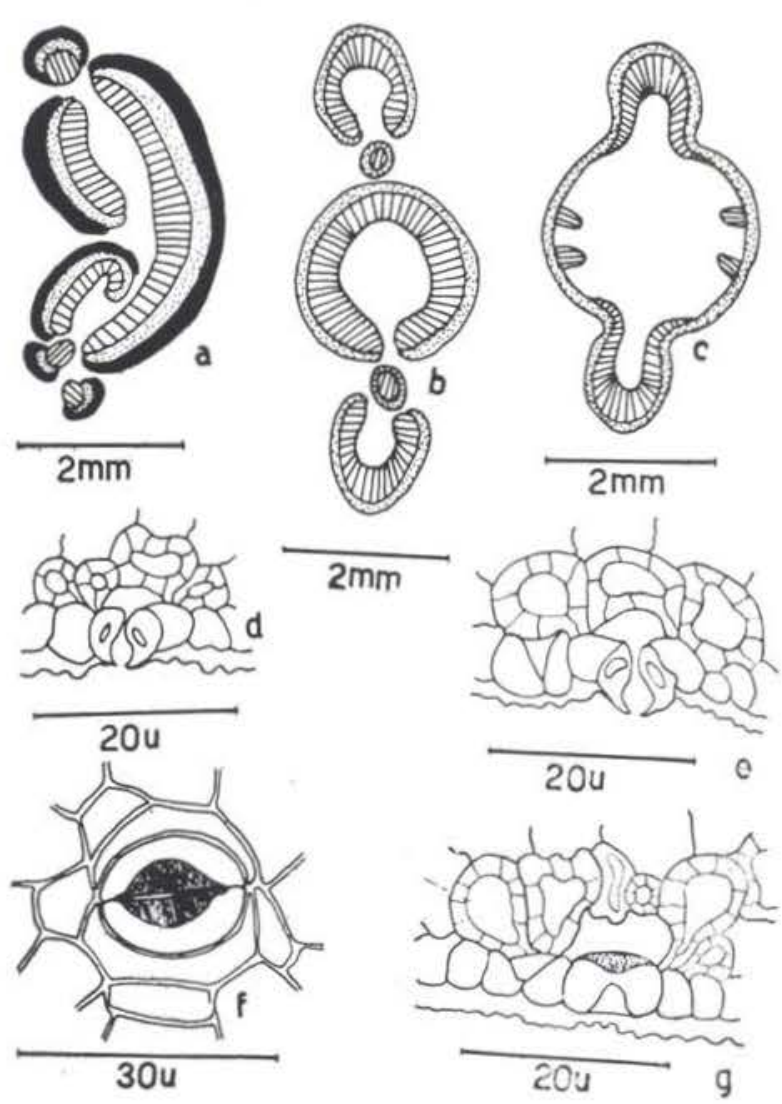

Fig. 6-Clusia aff macropoda - a) sistema fibrovascular da nervura central; b) sistema vascular da porção superior do nó foliar mostrando dois feixes vasculares do rastro foliar, e dois feixes menores das gemas axilares; c) sistema vascular da parte inferior do nó foliar mostrando o começo do deslocamento e dois cordóes vasculares, do cilindro central; d) estômato em corte transversal passando pela porção mediana, onde se vêem esclerócitos subepidérmicos; e) estômato em corte transversal passando pela porção polar, vê-se hipoder me esclerosada; f) epiderme adaxial em vista frontal; g) estômato em secção longitudinal. 

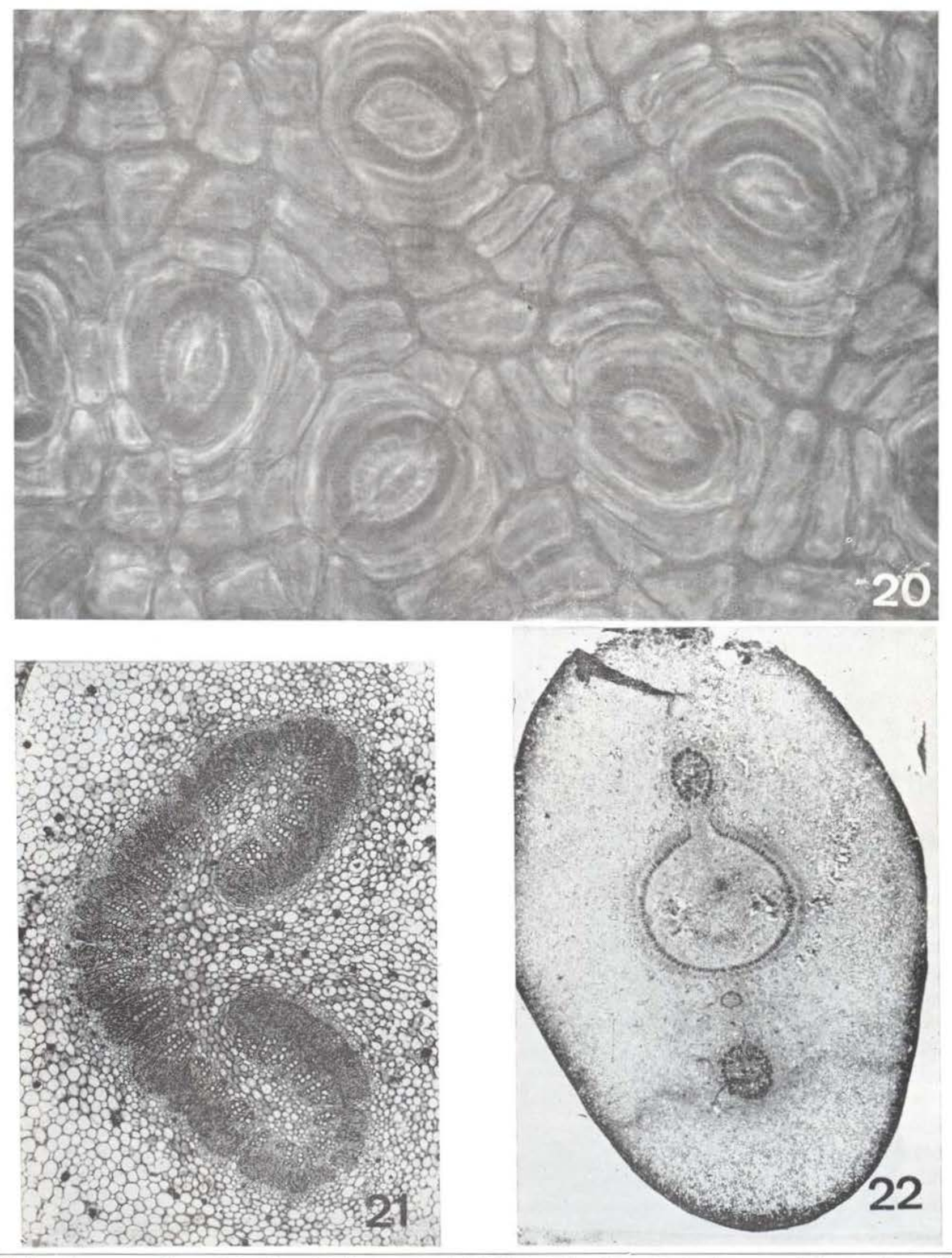

Clusia aff macropoda - Foto 20 - Epiderme abaxial (305x); Foto 21 - Corte transversal da porção médin do peciolo (60x); Foto 22 - Corte transversal do caule ao nivel do nó foliar (20x). 
A cutícula senso lato é uniforme, com cerca de $8 \mu \mathrm{m}$ de espessura. A epiderme, vista de face apresenta células tipicamente poligonais, de tamanho muito variado, com paredes finas, pectocelulósicas, sempre retas. A hipoderme consta de 3 camadas de células, sendo que, as duas primeiras, imediatamente abaixo da epiderme constam de esclerócitos poligonais, do tipo braquiesclerócitos (foto 19). Nos esclerócitos plenamente diferenciados, observamos vestígios de cristais e naqueles que estão em fase de esclerotização, por espessamento e lignifícação de suas paredes, observamos cristais em redissolução. A camada interna da hipoderme consta de células amplas, de paredes finas, pectocelulósicas. A epiderme abaxial (fig. 6-f) também é glabra; suas células, vistas em secção transversal, têm forma ha. bitualmente retangular, com maior diâmetro tangencial, em geral taníferas; em vista frontal, as células epidérmicas apresentam forma mui. to variada, predominando a forma retangular, com paredes finas, pectocelulósicas, sempre retas. A cutícula é uniforme, com 3 a $4 \mu \mathrm{m}$ de espessura. Logo abaixo da epiderme abaxial há também uma hipoderme com 1-2 camadas de esclerócitos (fig. 6-d, e, g, foto 24), geralmente com cristais em redissolução de outros com vestígios de cristais; entre esses esclerócitos ocorrem idioblastos de paredes finas, pectocelulósicas, contendo drusas de oxalato de cálcio. Quanto ao mesófilo, a folha dessa espécie é bifacial; o parênquima paliçádico é tão espesso quanto o lacunoso; aquele consta de duas camadas de células tipicamente paliçádicas. O parênquima lacunoso é repré. sentado por várias camadas de células de forma e tamanho variados; nesse parênquima raramente ocorrem canais secretores.

Nervura central - Com ambas epidermes glabras e cutícula crenulada de espessura entre 16 e $20 \mu \mathrm{m}$; abaixo da epiderme, também ocorrem 1-2 camadas de esclerócitos com cristais em redissolução. O sistema vascular, visto en secção transversal, consta de três cor-

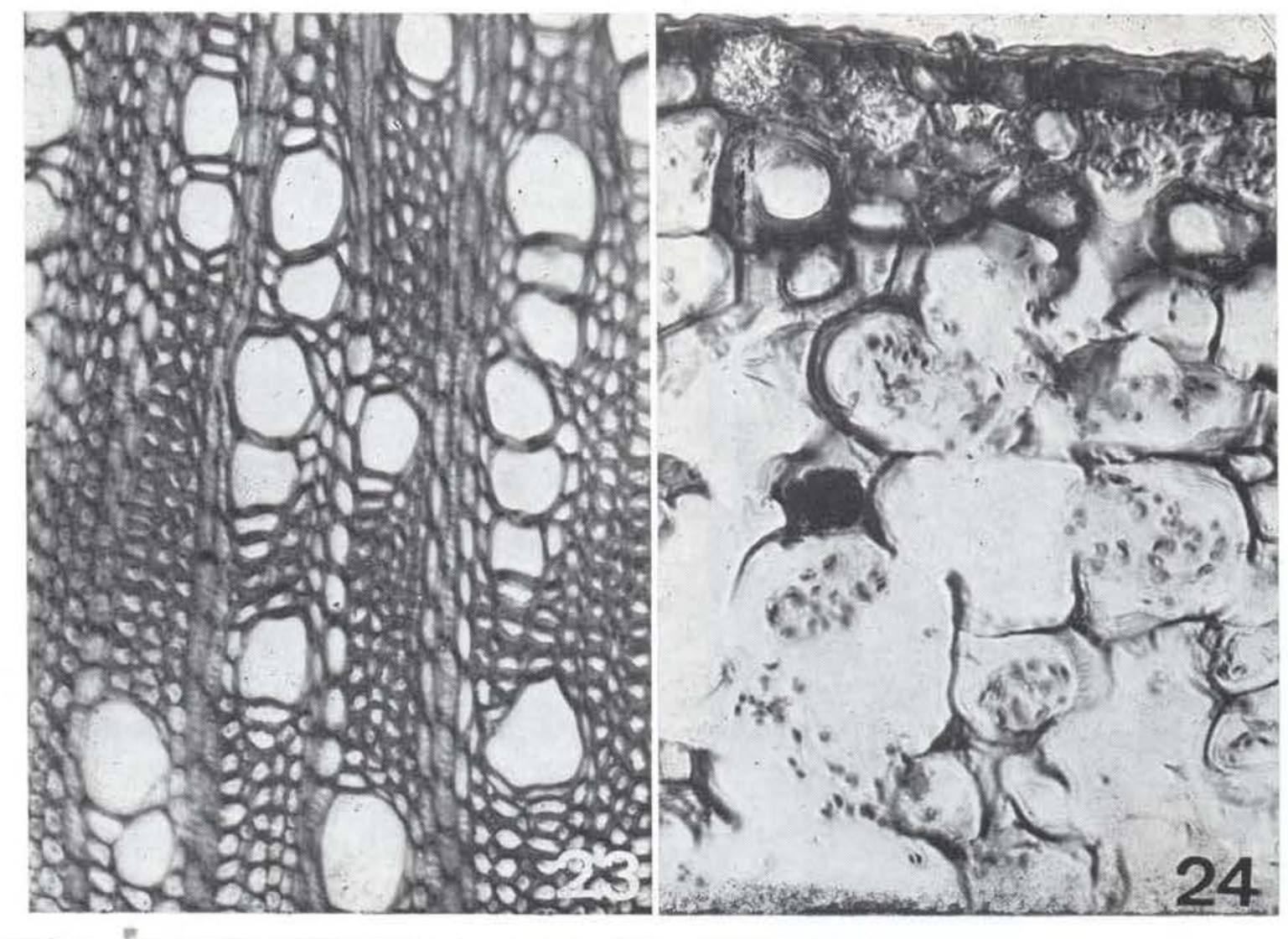

Clusia aff. macropoda - Foto 23 - Xilema da estrutura secundária (100x); Foto 24 - Corte transversal da la. mina foliar mostrando parte do mesófilo abaxial e células hipodérmicas com cristais em redissoluçāo (295x) 
dões vasculares, sendo um abaxial maior, em forma de arco e dois adaxiais menores; das extremidades dos cordões vasculares deslocam-se três cordões menores, sendo dois de um lado (fig. 6-a).

Estômatos - Ocoirem unicamente na epiderme abaxial, numa média de 139 por $\mathrm{mm}^{2}$, variando entre 136 e 142; são do tipo paracíticos (rubiáceos); vistos de face, observamos que as células guardiãs possuem, nas paredes, espessamento estriados (fig. 6-f, foto 20); em corte transversal (fig. 6-d, e), as células em questão apresentam estrutura semeIhante às dos estômatos de Lorostemon coelhoi, porém, a camara subestomática é pequena; em corte longitudinal, o lúmem das células guardiãs tem forma de "telefone" (fig. 6-g). O aparelho estomático é bastante grande.

\section{Discussão}

Canais secretores - $\mathrm{O}$ processo formador dos canais ou bolsas pode ser de natureza esquizógena, esquizolisigena e lisigena (Siek. 1895; Solereder, 1908; Harad, 1937; Engler, 1931; Milanez, 1946; Esau, 1959; Paula, 1972). Metcalfe \& Chalk (1957) afirmam que, uma das características das Guttiferae é a presença de canais secretores esquizógenos. Em Lorostemon coelhoi, Caraipa valioi, os canais sāo esquizolisigenos, enciuanto que em Clusia aff. macropoda, os canais são esquizolisigenos e esquizógenos, especialmente na raíz aérea. Quanto à localização dos canais, van Tieghen (1879) descreve os canais das Guttiferae situados no parênquima medular; Metcalfe \& Chalk (1957) salientam que, nas raizes das Guttiferae, os canais podem ocorrer somente no córtex ou no córtex e no floema, e no caule eles estão presentes no córtex, na meduia $\mathrm{e}$, às vezes, no floema da estrutura primária. ocorrendo também no floema secundário de Mammae. No caule de Lorostemon coelhoi. Caraipa valioi e Clusia aff. macropoda, os canais estẫo localizados no parênquima cortical e na medula, e igualmente na raiz aérea da referida espécie de Clusı.

Lâmina foliár - Nas Guttiferae, é muito comúm a ocorrência de hipoderme, porém, ela é ausente em Lorostemon coelhoi. Em Caraipa valioi e Clusia aff. macropoda, a hipoderme é esclerosada, constituída de esclerócitos típicos. Em C. aff. macropoda, a hipoderme ocorre nas duas faces da lâmina foliar, e em cujos esclerócitos, plenamente diferenciados, há fragmentos de cristais de oxalato de cálcio, e nos esclerócitos em processo de esclerotizaçâo, ocorrem cristais em redissolução concomitantemente à lignificação das paredes desse esclerócitos. Esse fenômeno foi observado e descrito pela primeira vez por Milanez (1938a, 1938b e 1946) que atribuiu uma certa relação entre a redissolução dos cristais e a lignificaçäo; ultimamente Paula (1973). observou esse mesmo fenômeno em Catostemma e Scleronema. Fato digno de nota é que entre os esclerócitos da referida hipoderme ocorrem células com paredes finas pectocelulósicas contendo drusas de oxalato de cálcio, íntegras. $\mathrm{Na}$ obra fundamental de Warming (1909) não está consignado hipoderme esclerosada para as plantas heliófilas e nem ciófilas. Entretanto Milanez (1940), observou hipoderme esclerosada em Coccoloba cereifera, espécime do Campo Rupestre da Serra do Cipó. Acredita. mos que não é esse o caso de Caraipa valioi e Clusia aff. macropoda, tendo em vista que, a primeira é espécie higrófila da mata da terra firme da Amazônia e a segunda igualmente higrófila, porém coletada na margem do rio $\mathrm{Ne}$. gro, sm solo rico em "laterita", também, da Amazônia. Este fato quue acabamos de apre sentar é uma questăo em aberto.

Metcalfe \& Chalk (1957) salientam mesófilo $\mathrm{ccm}$ tendência à esclerotização em vários gêneros de Guttiferae, e células paliçádicas com paredes reticuladamente espassadas em Clusia rosea. Em Lorostemon coelhoi, habitualmente, as células do parênquima paliçádi. co também apresentam esse caráter, porém com paredes parcialmente lignificadas. Quanto ao parênquima paliçádico, $C$. valioi e $L$. coelhoi têm uma camada de células, enquanto que C. aff. macropoda tem duas camadas. A diferença do número de estômatos por $\mathrm{mm}^{2}$ entre Clusia aff. macropoda e Clusia grandiflora (104 estomatos) é apenas de 35 estomatos (Paula, 1966). Quanto às madeiras, há uma característica acentuada: no gênero Caraipa, o parênqu: ma axial é paratraqueal vasicêntrico, enquantc que em Lorostemon esse parênquima é para. traqueal confluente. 


\section{CONCLUSÕES}

a) O sistema vascular primário de Caraipa valioi, Lorostemon coelhoi e Clusia aff. macropoda é do tipo sifonstelo-ectoflóico.

b) Em C. aff. macropoda, o caule não forma súber, pelo menos, até às fases que examinamos e a epiderme permanece íntegra.

c) Os canais secretores são esquizolisigenos nas três espécies estudadas e esquizógenos na raíz aérea de $C$. aff. macropoda; ocorrem no caule, na folha, na raíz e no ovário; no caule e na raíz eles estão localizados no parênquima cortical e na medula; formam-se na estrutura primária indiferenciada (meristema primário) e na estrutura primária diferenciada.

d) Lorostemon coelhoi não tem hipoderme foliar; em C. aff. macropoda e C. valioi, a hipoderme esclerosada nas duas faces da lâmina foliar, onde ocorrem cristais em redissolução concomitantemente à lignificação e ao espessamento das paredes celulares dos escierócitos.

e) As folhas de $C$. valioi e $C$. aff. macropoda são esclerófilas.

f) Lorostemon coelhoi e Caraipa valioi possuem na folha, apenas uma camada de células paliçádicas, enquanto que Clusia possui duas camadas.

g) o número de estômatos por $\mathrm{mm}^{2}$ de C. valioi é muito alto em comparação com o de $C$. aff. macropoda e $L$. coelhoi; o lúmem da célula guardiã de $C$. aff. macropoda tem forma de "telefone".

h) $\mathrm{Na}$ raíz aérea de Clusia, o felogênio é subepidérmico, fato que não é comum, nas raízes

i) As fibras das madeiras são espessas; os elementos fibrosos são de curtos a médios; em Caraipa, o parênquima axilar é paratraqueal vasicêntrico, enquanto que em Lorostemon e paratraqueal confluente.

\section{Agradecimentos}

Ao Dr. F. R. Milanez, Professor Jorge Fontella, Professora Maria Artemísia, Dr. Paulo B. Cavalcante, Luiz Coêlho e Professor Byron W. Albuquerque, pela colaboração que nos foi prestada para a execuçăo deste trabalho.

\section{SUMMARY}

This paper is the continuation of a series of studies on Guttiferae of the Amazon Region. In this contribution is studied the petiole, the leaf-blade, and the stem of Lorostemon coelhoi, Caraipa valioi, and Clusia aff. macropoda; the wood of C. valioi and Lorostemon coelhoi, and aerial root of Clusia aff. macropoda.

Among the principal results the following are the most important: secretory canals are schizolisigenous in three species, and schizogenous in the root of Clusia aff. macropoda. Caraipa valioi and Clusia aff. macropoda have sclerosed hypoderm; crystals of calcium-oxalate in redissolution appear simultaneously in process of lignification, in hypodermal cells of Clusia aff. macropoda; sub-epidermis-phellogeny in the aerial root of Clusia aff. macropoda; Clusia aff. macropoda and Caraipa valioi are sclerophyllous

\section{BIBLIOGRAFIA CITADA}

DUCKE, A.

1935 - Plantes nouvelles peu connues de la Région Amazonienne, Arq. Inst. Biol. Veg , Rio de Janeiro, 1(3):21-73, 9 est.

ENGLER, A

1931 - Die naturlichen pflanzenfamilien. "Anacardiaceae". Leipzig, Wilhelm Engelman. $21 v$, ilust.; $3(5): 139-140$

EsAu, K.

1959 - Anatomia vegetal. Trad, por J. P. Rossell. Barcelona, Ed. Omega. 729 p., 85 est. $20 \mathrm{fig}$.

FróEs, R. E

1959 - Três espécies novas da flora amazôni. ca. Bol. Téc. Inst. Agr. Norte, Belém, $36: 151-153,1$ est.

HARAD, M

1937 - On distribution and construction of the resin canals in Rhus seccedones. Bot. Magazine, 51(811) : 423-435

KRIBS, D. A .

1935 - Salient lines of structural specialization in the wood rays of dicotyledons. Bot. Gaz., 96(3): 547-557, 7 fig., 1 tab.

MAGUIRE, B

1958 - Guttiferae. Bot. Mus, Leaf., Cambrid. ge, $18(4): 158-160,1$ est

metcalfe, C. R. \& Chall, $K$.

1957 - Anatomy of the dicotyledons. Oxford, Clarendon, 2v., v. 1, 724 p., 167 fig. 
Milanez, F. R.

1938a - Anatomia do lenho de Aspidosperma aquaticum. Arq. Inst. Biol. Veg., Rio de Janeiro, 47(1):65-70.

1938b - Observaçōes sobre células do lenho In: Primeira Reunião Sul-Americana de Botânica, Rio de Janeiro, v. 3, p. 297-339, 19 est.

1940 - Nota sobre a anatomia de Coccoloba cereifea Schwake. Rodriguesia, Rio de Janeiro, $14: 23-39$.

1946 - Canais secretores do "Marupá". Rodri. guesia, Rio de Janeiro, $20: 13-40,12$ est.

Milanez, F. R. \& A. M. Bastos

1960 - Glossário dos termos usados em anatomia de madeira. Rio de Janeiro, Irmâos \& Cia., Ed. 27 p.

O'Brien, T.P., Feder, N. \& McCully, M.E.

1964 - Polychromic staining of plant cell walls by Toluidine blue. Protoplasma, Cambridge, Mass, $59: 367-373,1$ foto $\mathrm{col}$.

PAULA, J. E. DE

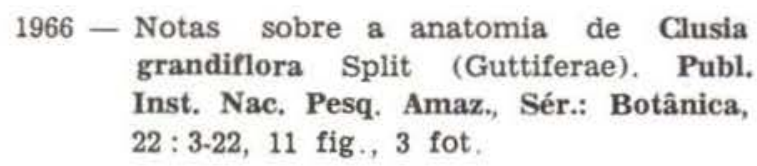
$22: 3-22$, 11 fig., 3 fot.
1969 - Anatomia de Caraipa valioi Paula (Guttiferae da Amazonia) Ciência e Cul- tura, São Paulo, 21(2): 433.

1970a - Anatomia de Lorostemon coelhoi Paula (Guttiferae da Amazonia) Ciência e Cultura, São Paulo, Resumos: 266-267.

1970b - Guttiferae novas da Amazônia. Ciência e Cultura, São Paulo, 22(4): 369-378, $22 \mathrm{fig}$.

REUNī̄o de ANATOMistas de MAdetra, I.

1937 - Rodriguésia, Rio de Janeiro, 11:305-384.

SOLEREDER, $\mathrm{H}$.

1908 - Sistematic anatomy of dicotyledons, transl. L. A. Boodle \& F. E. Fritch, from the German ed. of 1889. $2 \mathrm{v}$.

SIEK, W.

1895 - Die schyzolysigen sekre-tbehalter. Jahrb Wiss. Bot., 27 : 1-197.

TIEGHEM, M. PH, VAN

1872 - Memoire sur les canaux sécreteurs des plantes. An. Sc. Nat. Paris, 5. série; 16 : 96-201.

WARMINO, E.

1909 - Ecology plants, an introduction to the study of plant-communities, Oxford, Clarendon Press, $422 \mathrm{p}$. 